\title{
THERMOMECHANICAL ANALYSIS OF NITINOL MEMORY ALLOY BEHAVIOR
}

\author{
Nazarii Bykiv $^{1}$; Volodymyr Iasnii ${ }^{1}$; Petro Yasniy ${ }^{1}$; Robert Junga ${ }^{2}$ \\ ${ }^{I}$ Ternopil Ivan Puluy National Technical University, Ternopil, Ukraine \\ ${ }^{2}$ Opole University of Technology, Opole, Poland
}

\begin{abstract}
Summary. Shape memory alloys are functional materials characterized by the effect of shape memory and superelasticity. Due to these properties, they are widely used, particularly, in bioengineering, aeronautics, robotics and civil engineering. The temperatures of phase transformations and the influence of external temperature and strain rate on the functional and mechanical characteristics of $N i_{55.75} T_{44.15}$ shape memory alloy are investigated in this paper. The temperature of alloy phase transformations is obtained by differential scanning calorimetry (DSC) in the temperature range from $-70^{\circ} \mathrm{C}$ to $70^{\circ} \mathrm{C}$. Diagrams of differential scanning calorimeters at different heating and cooling rates of $\mathrm{Ni}_{55.75} \mathrm{Ti}_{44.15}$ alloy is constructed and analyzed. Samples for mechanical tests are made of round rod $8 \mathrm{~mm}$ in diameter. The samples working area is $12.5 \mathrm{~mm}$ in length and $4 \mathrm{~mm}$ in diameter. Mechanical tests are carried out at temperatures close to the maximum value of the completion temperature of martensitic-austenitic transformation $A_{f}=14.7^{\circ} \mathrm{C}$. Diagrams of deformation under uniaxial tension are constructed and stresses of phase transformations, Young's modulus and relative elongations of transformation areas at different loading speeds and exterior temperatures are determined. Using Clausius-Clapeyron formula, it is shown that with simultaneous changes in temperature and strain rate, the stresses of phase transformations are largely due to changes in temperature rather than load rates. The coefficients of Clausius-Clapeyron equation for superelastic $\mathrm{Ni}_{55.75} \mathrm{Ti}_{44.15}$ alloy with shape memory, which are consistent with those known in the literature, are determined.
\end{abstract}

Key words: shape memory alloys, stress-strain curve, temperature of phases transformation.

Statement of the problem. Shape memory alloys are functional materials characterized by the effect of shape memory and superelasticity. Due to these properties, they are widely used, particularly, in bioengineering [1, 2], aeronautics [3, 4], robotics [5] and civil engineering [6]. To predict the functional and structural properties of shape memory alloys, particularly when modeling their behavior, you should have its basic characteristics: the temperature of forward and reverse phases transitions, as well as functional and mechanical properties.

Analysis of known results. In civil engineering, SMA is considered as an alternative reinforcement of structures or their individual elements, or reduction of dynamic loads on structures and structures operating in seismic areas [7, 8]. It is known that functional and mechanical properties of the shape memory alloy in superelasticity state depend on temperature [9] and load speed. Even a small change in temperature can change such functional properties of superelastic shape memory alloy as the stress of austenitic-martensitic transformation, residual deformation, dissipation energy etc. On the other hand, increasing the strain rate increases the stress of austenitic transformation beginning and the curve slope in the area of austenitic-martensitic transformation $[9,10]$.

Objective of the paper is to determine the temperatures of phase transformations of NiTi shape memory alloy and investigate the influence of temperature and loading rate on the functional properties and mechanical properties characteristics. 
Statement of the task. In most cases, the effect of significant change in the strain rate on NiTi alloys behavior, for example, from $3.3 \cdot 10^{-5} \mathrm{~s}^{-1}$ up to $0.03 \mathrm{~s}^{-1}$ is investigated [9]. Higher strain rates increased the critical stress for martensite transformation due to the increase in sample temperature by latent conversion heat, which depends on the sample size and cannot be completely dissipated in the case of high strain rates [11]. Therefore, it is necessary to study the functional and mechanical behavior of shape memory alloys, taking into account the dimensions of the samples cross section and the strain rate. The results of the investigation of the temperature phase transformations and the influence of external temperature and strain rate on the functional properties and mechanical properties characteristics for $\mathrm{Ni}_{55.75} \mathrm{Ti}_{44.15}$.

Material and investigation methods. $\mathrm{NiTi}$ alloy of $\mathrm{Ni}_{55.75} \mathrm{Ti}_{44.15}$ formula (nitinol) in the form of the rod with $8 \mathrm{~mm}$ diameter, manufactured by Baoji Seabird Metal Material Co., LTD (China) is investigated. The alloy chemical composition stated in the certificate is as follows: Ni 55,75\%; Co 0,005\%; Cu 0,005\%; Cr 0,005\%; Fe 0,012\%; Nb 0,005\%; C0,036\%; $\mathrm{H}<0,001 \%$; $\mathrm{O} 0,031 \%$; Ti 44,15\%. The following mechanical characteristics are indicated in the certificate: uniaxial tensile strength - $895 \mathrm{MPa}$, yield strength - $320 \mathrm{MPa}$, elongation $20 \%$, temperature of austenite transformation completion $\mathrm{A}_{f}=15^{\circ} \mathrm{C}$.

Phase transformations in SMA are investigated by differential scanning calorimetry (DSC) on NETZSCH DSC 214 Polyma installation. Cylindrical samples weighing approximately $85 \mathrm{mg}$ and having $4 \mathrm{~mm}$ diameter, cut from rods with $8 \mathrm{~mm}$ diameter, are placed on crucible plate of Al standard. The gas flow rate is $35 \mathrm{ml} / \mathrm{min}$. The sample is heated and cooled from -70 to $70^{\circ} \mathrm{C}$ in $\mathrm{N}_{2}$ (nitrogen) atmosphere at $10,5,2,5,1,5^{\circ} \mathrm{C} / \mathrm{min}$ rates. To increase the results reliability, each cycle of heating and cooling is repeated four times.

The mechanical properties of SMA are determined in the air at temperatures $18.8^{\circ} \mathrm{C}$ and $22^{\circ} \mathrm{C}$ under uniaxial elongation of cylindrical samples with $4 \mathrm{~mm}$ working section diameter and $12.5 \mathrm{~mm}$ length of on STM-100 test machine by the method described in paper [12] according to the requirements standard [13].

The results of investigation. DSC analysis is presented in heat-temperature flow (F-T) coordinates: the curves show martensitic-austenitic (Fig. 1 a) and austeniticmartensitic (Fig. 1 b) phase transformations that occur in SMA during heating and cooling cycles, respectively. Comparison of phase transition temperatures confirms the inverse nature of the change in crystallographic structure of the investigated material. During heating, the phase transition occurs in the temperature range between $-24^{\circ} \mathrm{C}$ тa $9.6^{\circ} \mathrm{C}$ (average extrapolation), and the transition temperature is $-2,7^{\circ} \mathrm{C}$. DSC of $\mathrm{Ni}_{55.75} \mathrm{Ti}_{44.15}$ nitinol for each heating/cooling stage is shown in Figure 1.

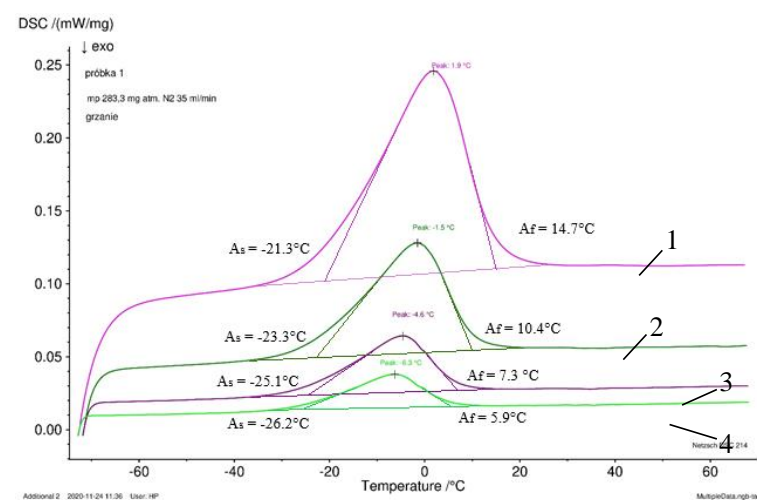

a

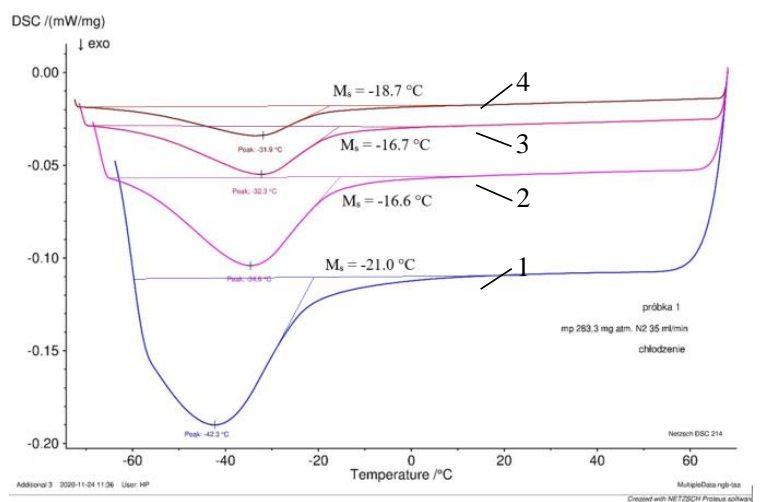

b

Figure 1. DSC analysis of shape memory alloy at rate of $10^{\circ} \mathrm{C} / \mathrm{min}(1), 5^{\circ} \mathrm{C} / \mathrm{min}(2)$, $2,5^{\circ} \mathrm{C} / \mathrm{min}$ (3) $1,5^{\circ} \mathrm{C} / \mathrm{min}$ (4) heating (a) and cooling (b) mode 
The largest enthalpy change caused by phase transitions in the rod is $19.53 \mathrm{j} / \mathrm{g}$ during heating and $13.59 \mathrm{j} / \mathrm{g}$ during cooling (Fig. 2 a).

The generalized results of the temperatures of phase transformations of the investigated SMA are presented in Table 1 (here $M_{s}, M_{f}, A_{s}, A_{f}$ are the temperatures of the beginning and end of martensitic and austenitic phases, respectively). It should be noted that the temperature of phase transformations in the rod material differ between individual cycles of heating (cooling). However, there are certain patterns of their change. With increasing speed from sample heating from $1.5^{\circ} \mathrm{C} / \mathrm{min}$ to $10^{\circ} \mathrm{C} / \mathrm{min}$ the temperatures of the beginning and end of austenitic transformation $\left(A_{\mathrm{s}}\right.$ and $\left.A_{f}\right)$ increase and the temperature of the beginning of martensitic phase $M_{s}$ decreases. The obtained regularities are consistent with the results of other authors, particularly for NiTiCu shape memory alloy $[14,15]$.

\section{Table 1}

Temperatures of nitinol alloy phase transformations

\begin{tabular}{|c|c|c|c|c|}
\hline \multirow{2}{*}{ Heating/cooling } & $M_{s}$ & $M_{f}$ & $A_{s}$ & $A_{f}$ \\
\cline { 2 - 5 } & \multicolumn{3}{|c|}{${ }^{\circ} \mathrm{C}$} \\
\hline $10^{\circ} \mathrm{C} / \mathrm{min}$ & $-21,0$ & $<-60$ & $-21,3$ & 14,7 \\
\hline $5^{\circ} \mathrm{C} / \mathrm{min}$ & $-16,6$ & $<-60$ & $-23,3$ & 10,4 \\
\hline $2,5^{\circ} \mathrm{C} / \mathrm{min}$ & $-16,7$ & $<-60$ & $-25,1$ & 7,3 \\
\hline $1,5^{\circ} \mathrm{C} / \mathrm{min}$ & $-18,7$ & $<-60$ & $-26,2$ & 5,9 \\
\hline Average value & $-18,3$ & $<-60$ & -24 & 9,6 \\
\hline
\end{tabular}

Mechanical tests are carried out at temperatures close to the maximum temperature value of martensitic-austenitic transformation completion $\mathrm{A}_{f}=14.7^{\circ} \mathrm{C}$.

The first sample is investigated at air temperature $\mathrm{T}=18.8^{\circ} \mathrm{C}$. The loading rate of the sample before deformation $6 \%$ is $0.00208 \mathrm{~mm} / \mathrm{s}$. After that, the sample is unloaded and reloaded by tension to complete rupture at $0.0208 \mathrm{~mm} / \mathrm{s}$ rate. The second sample is investigated at air temperature $\mathrm{T}=22^{\circ} \mathrm{C}$. The loading rate of the sample before deformation $6 \%$ is $0.0045 \mathrm{~mm} / \mathrm{s}$. After unloading, the rate of reloading of the sample before failure is $0.045 \mathrm{~mm} / \mathrm{s}$.

From the constructed diagrams of stress-strain states for SMA (Fig. 2, 3) the following main thermomechanical parameters are obtained (derived) (Table 2): Young's modules $\left(E_{\mathrm{A}}\right.$, $\left.E_{\mathrm{M}}\right)$, stress $\left(\sigma_{\mathrm{s}}^{\mathrm{AM}}, \sigma_{f}^{\mathrm{AM}}, \sigma_{\mathrm{s}}^{\mathrm{MA}}, \sigma_{f}^{\mathrm{MA}}\right)$ and transformations elongation $\left(\varepsilon_{\mathrm{L}}\right)$.

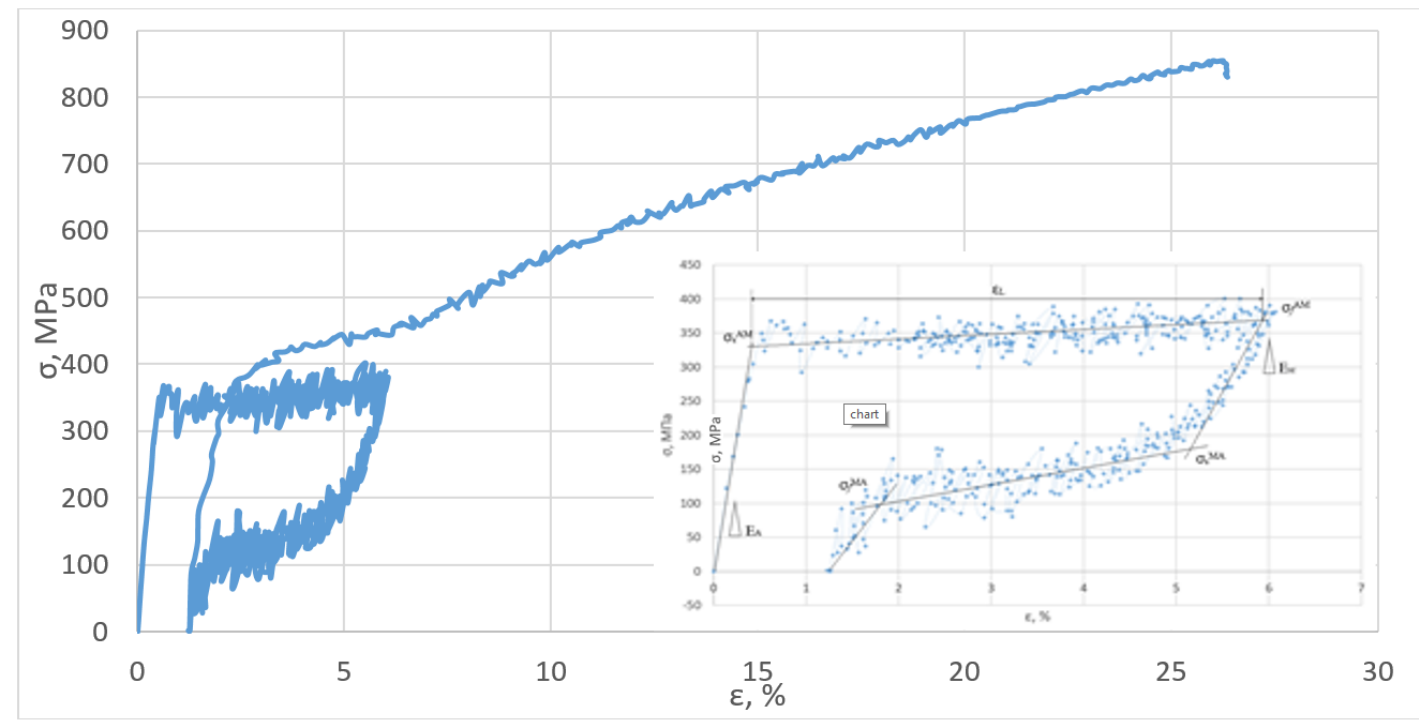

Figure 2. Stress-strain curve of SMA at temperature $18,8^{\circ} \mathrm{C}$ 
Due to the large scatter of values for the diagram (Fig. 2), the data are approximated while constructing the hysteresis loop. This scatter is caused by the slow loading rate of the sample.

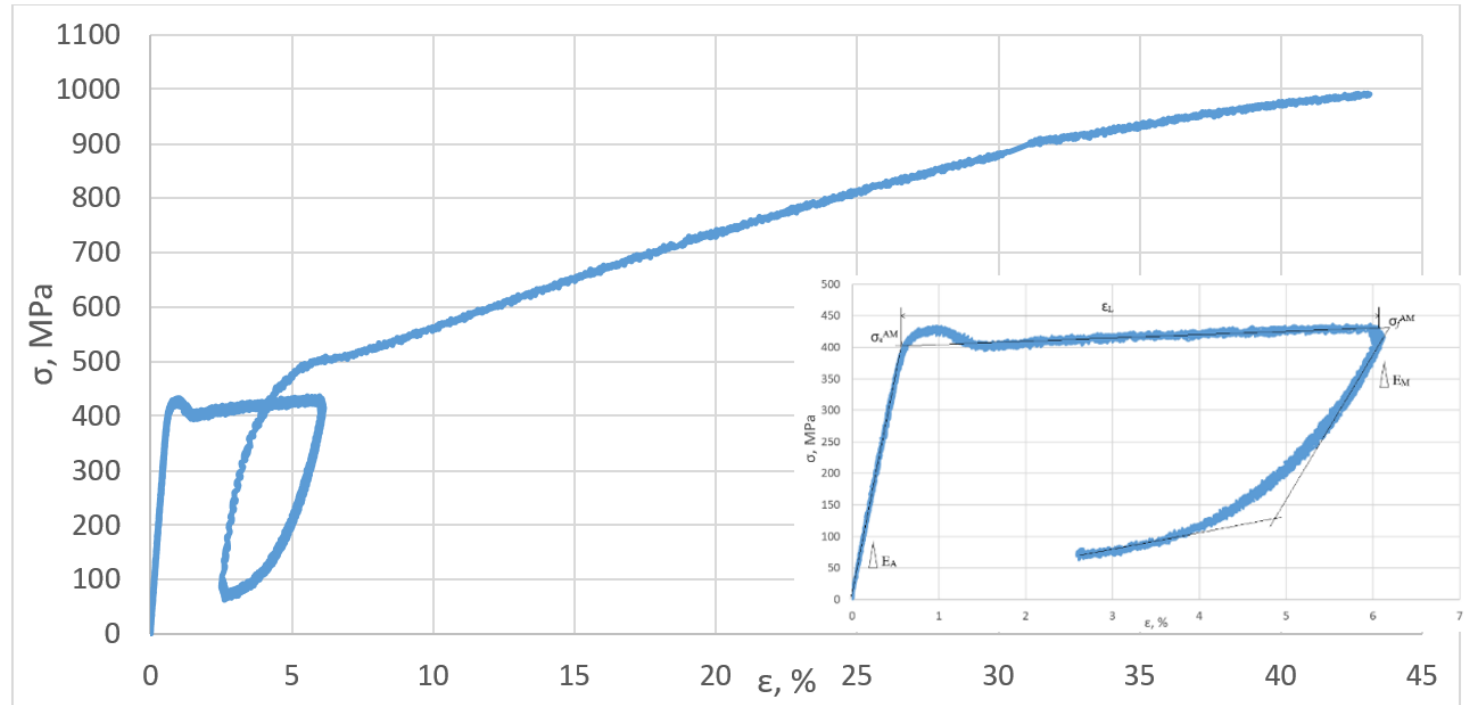

Figure 3. Stress strain curve of SMA at temperature $22^{\circ} \mathrm{C}$

Table 2

The main thermomechanical parameters of SMA

\begin{tabular}{|c|c|c|c|c|c|c|c|c|c|}
\hline Sample № & $\mathrm{T},{ }^{\circ} \mathrm{C}$ & $\sigma_{\mathrm{s}}{ }^{\mathrm{AM}}, \mathrm{MPa}$ & $\sigma_{\mathrm{f}}^{\mathrm{AM}}, \mathrm{MPa}$ & $\sigma_{\mathrm{s}}{ }^{\mathrm{MA}}, \mathrm{MPa}$ & $\sigma_{\mathrm{f}}{ }^{\mathrm{MA}}, \mathrm{MPa}$ & $\mathrm{E}_{\mathrm{A}}, \mathrm{GPa}$ & $\mathrm{E}_{\mathrm{M}}, \mathrm{GPa}$ & $\varepsilon_{\mathrm{L},} \%$ & $\varepsilon_{\mathrm{L},}, 10^{-3} \mathrm{~s}^{-1}$ \\
\hline 1 & 18,8 & 332 & 368 & 174 & 103 & 72.4 & 18.7 & 5.4 & 2.25 \\
\hline 2 & 22 & 408 & 428 & - & - & 68.2 & 19.2 & 5.5 & $3.4,4$ \\
\hline
\end{tabular}

The obtained characteristics of SMA from the investigations are slightly different from those specified in the certificate (table 3 ). Thus, the yield strength $\left(\sigma_{0.2}\right)$ is $3.75 \%$ higher than that one specified in the certificate (sample 1) and $27.5 \%$ higher than specified in the certificate (sample 2); tensile strength $\left(\sigma_{u}\right)$ is higher by $4.58 \%$ and lower by $10.7 \%$; the maximum relative elongation $\left(\varepsilon_{\max }\right)$ is lower by $6.3 \%$ and $23.1 \%$ relatively to the samples 1 and 2 , respectively. The temperature of austenitic phase completion $\left(A_{f \max }\right)$ is higher by $0.3^{\circ} \mathrm{C}$ relatively to DSC results.

Clausius-Clapeyron formula adapted to shape memory alloys is used in order to understand whether the load velocity affects the alloy characteristic loop or this is the effect of external temperature [16].

$$
\frac{d \sigma}{d T}=-\frac{\rho \Delta S}{\varepsilon}
$$

where $\sigma$ is the stress; $\mathrm{T}$ is the temperature; $\rho$ is the alloy density; $\Delta \mathrm{S}$ is the enthalpy change, $\varepsilon$ is the relative elongation of the phase transformation. The determined Clausius-Clapeyron coefficients (Table 3 ) indicate that the difference in stresses of phase transformations is largely due to the changes in temperatures, not the loading rate. 
Table 3

Comparison of given and obtained characteristics of SMA

\begin{tabular}{|c|c|c|c|c|c|c|c|}
\hline & $\mathrm{T},{ }^{\circ} \mathrm{C}$ & $\sigma_{0.2}, \mathrm{MPa}$ & $\sigma_{\mathrm{u}}, \mathrm{MPa}$ & $\varepsilon_{\max }, \%$ & $A_{f \max }{ }^{\circ} \mathrm{C}$ & $\begin{array}{c}d \sigma / d T, \\
\mathrm{MPa} /{ }^{\circ} \mathrm{C}\end{array}$ & $\begin{array}{c}-\rho \Delta S / \varepsilon, \\
\mathrm{MPa} /{ }^{\circ} \mathrm{C}\end{array}$ \\
\hline Certificate & - & 320 & 895 & 20 & 15 & - & - \\
\hline Sample 1 & 18,8 & 332 & 854 & 26.3 & \multirow{2}{*}{14.7} & 23.8 & 23.6 \\
\hline Sample 2 & 22 & 408 & 991 & 43.1 & & \\
\hline
\end{tabular}

Conclusions. The temperatures of phase transformations for $\mathrm{Ni}_{55.75} \mathrm{Ti}_{44.15}$ shape memory alloy are determined by means of DSC method. As the heating rate of the sample increases from $1.5^{\circ} \mathrm{C} / \mathrm{min}$ to $10^{\circ} \mathrm{C} / \mathrm{min}$, the temperatures of the beginning and end of austenitic transformation $\left(A_{\mathrm{s}}\right.$ and $\left.A_{f}\right)$ increase and the temperature of the beginning of martensitic phase $M_{\mathrm{s}}$.

The influence of the external temperature of tensile deformation diagram, the characteristics of mechanical and functional properties of $\mathrm{Ni}_{55.75} \mathrm{Ti}_{44.15}$ alloy, particularly the value of the stress of phase transformations at temperatures above the temperature of austenitic phase completion are investigated. It is confirmed that the effect of temperature on the stress of phase transformations can be described by Clausius-Clapeyron equation adapted to shape memory alloys.

\section{References}

1. Morgan N. B. Medical shape memory alloy applications - The market and its products. Mater. Sci. Eng. A. 2004. Vol. 378. No. 1-2 SPEC. ISS. P. 16-23. DOI: https://doi.org/10.1016/j.msea.2003.10.326

2. Nematollahi M. et al. Application of NiTi in Assistive and Rehabilitation Devices: A Review. Bioengineering. Multidisciplinary Digital Publishing Institute, 2019. Vol. 6. No. 2. P. 37. DOI: https://doi.org/10.3390/bioengineering6020037

3. Mohd Jani J. et al. A review of shape memory alloy research, applications and opportunities. Mater. Des. Elsevier Ltd, 2014. Vol. 56. P. 1078-1113. DOI: https://doi.org/10.1016/j.matdes.2013.11.084

4. Pecora R., Dimino I. SMA for Aeronautics. Shape Mem. Alloy Eng. Butterworth-Heinemann, 2015. P. 275-304. DOI: https://doi.org/10.1016/B978-0-08-099920-3.00010-3

5. Zeng Z. et al. Fabrication and characterization of a novel bionic manipulator using a laser processed NiTi shape memory alloy. Opt. Laser Technol. Elsevier. 2020. Vol. 122. 105876. DOI: https://doi.org/10.1016/j.optlastec.2019.105876

6. Isalgue A. et al. SMA for Dampers in Civil Engineering. Mater. Trans. 2006. Vol. 47. No. 3. P. 682-690. DOI: https://doi.org/10.2320/matertrans.47.682

7. Morais J. et al. Shape Memory Alloy Based Dampers for Earthquake Response Mitigation. Procedia Struct. Integr. Elsevier, 2017. Vol. 5. P. 705-712. DOI: https://doi.org/10.1016/j.prostr.2017.07.048

8. Dolce M. et al. Shaking table tests on reinforced concrete frames without and with passive control systems. Earthq. Eng. Struct. Dyn. 2005. Vol. 34. No. 14. P. 1687-1717. DOI: https://doi.org/10.1002/eqe.501

9. Dayananda G. N., Rao M. S. Effect of strain rate on properties of superelastic NiTi thin wires. Mater. Sci. Eng. A. 2008. Vol. 486. No. 1-2. P. 96-103. DOI: https://doi.org/10.1016/j.msea.2007.09.006

10. Entemeyer D. et al. 2000_Strain rate sensitivity in superelasticity_Entemeyer. Int. J. Plast. Elsevier, 2000. Vol. 16. P. 273-274. DOI: https://doi.org/10.1016/S0749-6419(00)00044-9

11. Rodrigues M. C. M. et al. INFLUENCE OF STRAIN RATE ON THE FUNCTIONAL BEHAVIOR OF A NITI ALLOY UNDER PSEUDOELASTIC TRAINING // 71th ABM Annual Congress, Rio de Janeiro, 2016. Editora Edgard Blucher, Ltda., 2016. P. 118-127. 
12. Iasnii V., Junga R. Fazovi peretvorennia ta mekhanichni vlastyvosti splavu nitynol zpam'iattiu formy. Fizyko-khimichna mekhanika materialiv. 2018. Vol. 54. No. 3. P. 107-111. [In Ukraine]. DOI: https://doi.org/10.1007/s11003-018-0199-7

13. ASTM F2516-14. Standard Test Method for Tension Testing of Nickel-Titanium Superelastic Materials. Book of Standards Volume: 13.02. 2014.

14. Wang Z. G., Zu X. T., Huo Y. Effect of heating/cooling rate on the transformation temperatures in TiNiCu shape memory alloys. Thermochim. Acta. 2005. Vol. 436. No. 1-2. P. 153-155. DOI: https://doi.org/10.1016/j.tca.2005.06.028

15. Çakmak U. D., Major Z., Fischlschweiger M. Mechanical consequences of dynamically loaded niti wires under typical actuator conditions in rehabilitation and neuroscience. J. Funct. Biomater. 2021. Vol. 12. No. 1. P. 11-17. DOI: https://doi.org/10.3390/jfb12010004

16. Kök M. et al. The change of transformation temperature on NiTi shape memory alloy by pressure and thermal ageing. J. Phys. Conf. Ser. 2016. Vol. 667. No. 1. DOI: https://doi.org/10.1088/1742-6596/667/1/012011

\section{Список використаної літератури}

1. Morgan N. B. Medical shape memory alloy applications - The market and its products. Mater. Sci. Eng. A. 2004. Vol. 378. No. 1-2 SPEC. ISS. P. 16-23. DOI: https://doi.org/10.1016/j.msea.2003.10.326

2. Nematollahi M. et al. Application of NiTi in Assistive and Rehabilitation Devices: A Review. Bioengineering. Multidisciplinary Digital Publishing Institute, 2019. Vol. 6. No. 2. P. 37. DOI: https://doi.org/10.3390/bioengineering6020037

3. Mohd Jani J. et al. A review of shape memory alloy research, applications and opportunities. Mater. Des. Elsevier Ltd, 2014. Vol. 56. P. 1078-1113. DOI: https://doi.org/10.1016/j.matdes.2013.11.084

4. Pecora R., Dimino I. SMA for Aeronautics. Shape Mem. Alloy Eng. Butterworth-Heinemann, 2015. P. 275-304. DOI: https://doi.org/10.1016/B978-0-08-099920-3.00010-3

5. Zeng Z. et al. Fabrication and characterization of a novel bionic manipulator using a laser rocessed NiTi shape memory alloy. Opt. Laser Technol. Elsevier. 2020. Vol. 122. 105876. DOI: https://doi.org/10.1016/j.optlastec.2019.105876

6. Isalgue A. et al. SMA for Dampers in Civil Engineering. Mater. Trans. 2006. Vol. 47. No. 3. P. 682-690. DOI: https://doi.org/10.2320/matertrans.47.682

7. Morais J. et al. Shape Memory Alloy Based Dampers for Earthquake Response Mitigation. Procedia Struct. Integr. Elsevier, 2017. Vol. 5. P. 705-712. DOI: https://doi.org/10.1016/j.prostr.2017.07.048

8. Dolce M. et al. Shaking table tests on reinforced concrete frames without and with passive control systems. Earthq. Eng. Struct. Dyn. 2005. Vol. 34. No. 14. P. 1687-1717. DOI: https://doi.org/10.1002/eqe.501

9. Dayananda G. N., Rao M. S. Effect of strain rate on properties of superelastic NiTi thin wires. Mater. Sci. Eng. A. 2008. Vol. 486. No. 1-2. P. 96-103. DOI: https://doi.org/10.1016/j.msea.2007.09.006

10. Entemeyer D. et al. 2000_Strain rate sensitivity in superelasticity_Entemeyer. Int. J. Plast. Elsevier, 2000. Vol. 16. P. 273-274. DOI: https://doi.org/10.1016/S0749-6419(00)00044-9

11. Rodrigues M. C. M. et al. INFLUENCE OF STRAIN RATE ON THE FUNCTIONAL BEHAVIOR OF A NITI ALLOY UNDER PSEUDOELASTIC TRAINING // 71th ABM Annual Congress, Rio de Janeiro, 2016. Editora Edgard Blucher, Ltda., 2016. P. 118-127.

12. Iasnii V., Junga R. Fazovi peretvorennia ta mekhanichni vlastyvosti splavu nitynol zpam'iattiu formy. Fizyko-khimichna mekhanika materialiv. 2018. Vol. 54. No. 3. P. 107-111. [In Ukraine]. DOI: https://doi.org/10.1007/s11003-018-0199-7

13. ASTM F2516-14. Standard Test Method for Tension Testing of Nickel-Titanium Superelastic Materials. Book of Standards Volume: 13.02. 2014.

14. Wang Z. G., Zu X. T., Huo Y. Effect of heating/cooling rate on the transformation temperatures in $\mathrm{TiNiCu}$ shape memory alloys. Thermochim. Acta. 2005. Vol. 436. No. 1-2. P. 153-155. DOI: https://doi.org/10.1016/j.tca.2005.06.028

15. Çakmak U. D., Major Z., Fischlschweiger M. Mechanical consequences of dynamically loaded niti wires under typical actuator conditions in rehabilitation and neuroscience. J. Funct. Biomater. 2021. Vol. 12. No. 1. P. 11-17. DOI: https://doi.org/10.3390/jfb12010004

16. Kök M. et al. The change of transformation temperature on NiTi shape memory alloy by pressure and thermal ageing. J. Phys. Conf. Ser. 2016. Vol. 667. No. 1. DOI: https://doi.org/10.1088/1742-6596/667/1/012011 


\title{
УДК 539.3
}

\section{ТЕРМОМЕХАНІЧНИЙ АНАЛІЗ ПОВЕДІНКИ СПЛАВУ 3 ПАМ'ЯТТЮ ФОРМИ НІТИНОЛ}

\section{Назарій Биків ${ }^{1}$; Петро Ясній ${ }^{1}$; Володимир Ясній ${ }^{1}$; Роберт Юнга ${ }^{2}$}

\author{
${ }^{1}$ Тернопільський національний технічний університет імені Івана Пулюя, \\ Тернопіль, Україна \\ ${ }^{2}$ Політехніка Опольська, Ополе, Польща
}

\begin{abstract}
Резюме. Сплави з пам'яттю форми - цее функціональні матеріали, які характеризуються ефектом запам'ятовування форми та надпружністю. Завдяки ичим властивостям вони широко використовуються, зокрема, в біоінженеріі, аеронавтиці, робототехніці та циивільному будівництві. Досліджено температури фазових перетворень та вплив зовнішньої температури $i$ швидкості деформування на функиіональні й механічні характеристики сплаву з пам'яттю форми $\mathrm{Ni}_{55.75} \mathrm{Ti}_{44.15}$. Температури фазових перетворень сплаву отримано за допомогою диференціальної сканувальної калориметрї (DSC) у діапазоні температур від $-70^{\circ} \mathrm{C}$ до $70^{\circ} \mathrm{C}$. Побудовано та проаналізовано діаграми диферениіальних сканувальних калориметрій за різних швидкостей нагрівання та охолодження сплаву $\mathrm{Ni}_{55.75} \mathrm{Ti}_{44.15}$. Зразки для механічних випробувань виготовлено з круглого стержня діаметром 8 тт. Робоча ділянка зразків була завдовжки 12,5 mm та діаметром в 4 тm. Механічні випроби здійснювали за температур, близьких до максимального значення температури завершення мартенситноаустенітного перетворення $A_{f}=14,7^{\circ} \mathrm{C}$. Побудовано діаграми деформування за одновісного розтягу та визначено напруження фазових перетворень, модуль Юнта та відносні видовження ділянок трансформацій за різних швидкостей навантаження й температур зовнішнього середовища. 3 використанням формули Клаузіуса-Клапейрона показано, щяо за одночасної зміни температури $i$ швидкості деформування, напруження фазових перетворень більше зумовлені зміною температур, а не швидкістю навантаження. Визначено коефіцієнти рівняння Клаузіуса-Клапейрона для надпружного сплаву з пам'яттю форми $\mathrm{Ni}_{55.75} \mathrm{Ti}_{44.15}$, які узгоджуються з відомими в літературі.
\end{abstract}

Ключові слова: сплави з пам'яттю форми, діаграма деформування, температури фазових перетворень. 